\title{
From Intention to Action: Hierarchical Sensorimotor Transformation in the Posterior Parietal Cortex ${ }^{1,2}$
}

\author{
He Cui
}

DOI:http://dx.doi.org/10.1523/ENEURO.0017-14.2014

Brain and Behavior Discovery Institute and Department of Psychiatry and Health Behavior, Medical College of Georgia, Georgia Regents University, Augusta, Georgia 30912

Key words: action selection; decision making; reference frame; sensorimotor integration; sequential movement

\section{Significance Statement}

While there is a large body of evidence in favor of a clustering of representations of body effectors in the posterior parietal cortex, recent advances have revealed a hierarchical organization beyond a flat intentional map composed of functionally distinct subdivisions operating in parallel at same level. In particular, the parietal reach region (PRR) and dorsal area 5 (area $5 \mathrm{~d}$ ) have been found to play distinct roles in visuallyguided reach. Based on three lines of neurophysiological studies on nonhuman primates that utilize sophisticated behavioral tasks, including reference frame, effector choice, and sequential reach, this essay proposes that the PRR and area $5 d$ are involved in translation of general motor intentions into detailed motor programs at different stages.

\section{Introduction}

The posterior parietal cortex (PPC) has historically been considered a typical association cortex, important for spatial attention and multisensory integration in the generation of a unitary map whose output is relayed to the frontal lobe to guide behavior (Critchley, 1953; Ungerleider and Mishkin, 1982; Colby and Goldberg, 1999). Since the 1970s, tremendous progress in neurophysiology, neuroanatomical tracing, functional imaging, and experimental intervention has

Received September 1, 2014; accepted October 23, 2014; First published November 12, 2014.

${ }^{1}$ Author reports no conflict of interest.

${ }^{2}$ Author contributions: H.C. designed research; H.C. wrote the paper.

This work was supported by Whitehall Foundation and Alfred P. Sloan Research Fellowship. I thank R.A. Andersen, D. Baldauf, D. Blake, Y. Li, A. Saul, Y. Wang, and Z. Yang for helpful discussions, and J.G. Malpeli for critical comments on the manuscript.

Correspondence should be addressed to Brain and Behavior Discovery Institute, Georgia Regents University, Augusta, GA 30912. E-mail: hcui@gru.edu.

DOI:http://dx.doi.org/10.1523/ENEURO.0017-14.2014

Copyright $\odot 2014$ Cui

This is an open-access article distributed under the terms of the Creative Commons Attribution License Attribution-Noncommercial 4.0 International which permits noncommercial reuse provided that the original work is properly attributed. yielded evidence of a variety of distinct functional subareas in the PPC, as opposed to a homogeneous area that constructs a single unified perceptual representation (Rizzolatti et al., 1997; Mountcastle, 1998; Andersen and Buneo, 2002). Furthermore, the PPC has been shown to be involved in movement planning in a number of different contexts (Andersen and Cui, 2009; Rizzolatti and Kalaska, 2013). The PPC seems to be composed of a mosaic of intentional maps, each of which is thought to be specialized for a different kind of movement for a particular body part (Andersen and Buneo, 2002; Scherberger et al., 2013). Recent advances have further suggested that the individual effector-specific regions are heterogeneous (Heed et al., 2011; Leone et al., 2014), with a hierarchical organization among different subdivisions preferring the same effector (Cui and Andersen, 2011; Verhagen et al., 2013), indicating that some subareas in PPC are involved in sensorimotor integration at multiple levels, instead of working in parallel within a flat intentional map. This essay will focus on two reach-related areas in Brodmann's area 5 (Fig. 1A), the parietal reach region (PRR), and dorsal area 5 (area $5 d$ ), and discuss the functional relationship between them based on 
A
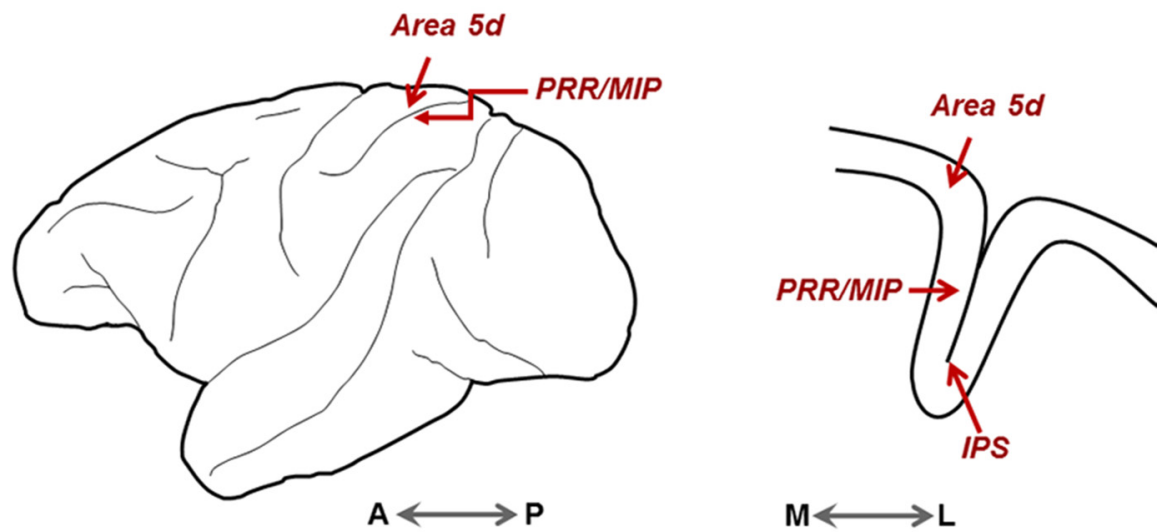

\begin{tabular}{cc|c} 
B & Sensory \\
input & $\begin{array}{c}\text { General } \\
\text { Motor } \\
\text { Intention }\end{array}$ & $\begin{array}{c}\text { Detailed } \\
\text { Motor } \\
\text { Program }\end{array}$ \\
$\begin{array}{c}\text { Reference } \\
\text { Frame }\end{array}$ & $\begin{array}{c}\text { Visual } \\
\text { coordinates }\end{array}$ & $\begin{array}{c}\text { Intrinsic } \\
\text { coordinates }\end{array}$ \\
$\begin{array}{c}\text { Decision } \\
\text { Making }\end{array}$ & $\begin{array}{c}\text { Potential } \\
\text { motor plans }\end{array}$ & $\begin{array}{c}\text { Selected motor } \\
\text { plan only }\end{array}$ \\
$\begin{array}{c}\text { Sequential } \\
\text { Movement }\end{array}$ & $\begin{array}{c}\text { Entire } \\
\text { sequence }\end{array}$ & $\begin{array}{c}\text { Elementary } \\
\text { action }\end{array}$ \\
& &
\end{tabular}

Figure 1 Anatomical and functional distinctions between two reach-related areas in the PPC. $\boldsymbol{A}$, Locations of the PRR (MIP) and area $5 \mathrm{~d}$. $\boldsymbol{B}$, Three paradigms to distinguish general motor intention from detailed motor programs. In the reference frame task, general motor intention is represented in extrinsic space, while physical movement is prepared in intrinsic space. In the effector-choice task, multiple potential action plans can be formed prior to specification of the concrete motor parameters controlling the end-effector. In the sequential reach task, an action sequence encompassing all motor components at a cognitive level is formed before it is unfolded into a series of detailed programs of element movements.

recent neurophysiological studies using a variety of sensorimotor contingencies.

The PRR was originally defined as an area medial and posterior to the lateral intraparietal area (LIP), including more than one cytotectonic area, whose cells are more active for reaching arm movements than for saccadic eye movements (Snyder et al., 1997; Quian Quiroga et al., 2006; Cui and Andersen, 2007). Many subsequent neurophysiological studies of the PRR have targeted the medial bank of the IPS (MIP) (Baldauf et al., 2008; Cui and Andersen, 2007, 2011; Pesaran et al., 2006, 2008; Scherberger and Andersen, 2007). Reversibly inactivating the PRR in monkeys causes miss-reach, similar to the optic ataxia reported in human patients (Hwang et al. 2012). In addition, pre-movement activity is not simply related to the cue, because the PRR has been found to encode the desired movement goal during an anti-reach task (Gail and Andersen, 2006). Moreover, the reaching plan embedded in the PRR includes not only target locations or end-points, but also high-level kinematics such as movement trajectories (Torres et al., 2013), supporting the view that movement trajectories are geometrically formed, independently of physical motor commands (Torres and Zipser, 2002; Torres and Andersen, 2006).

Area $5 \mathrm{~d}$, which is located caudal to the primary somatosensory cortex (SI) and medial to the IPS, is involved in representing spatial information for limbs and control of reaching arm movements (Lacquaniti et al. 1995; Kalaska 
et al. 1997). It receives major cortical inputs from SI (Jones et al. 1978; Pearson and Powell 1985), and is reciprocally interconnected with primary and premotor cortex (Strick and Kim, 1978). It was previously thought of as a higher somatosensory area that codes posture and joint positions (Sakata et al., 1973). However, studies on behaving monkeys demonstrate that cells in area 5 became much more active during arm movements (Mountcastle et al., 1975), with strong directional tuning (Kalaska et al., 1983). During delayed reach, many area 5 cells exhibit sustained activity far before the earliest increase in electromyographic activity (Kalaska and Crammond, 1995). Compared with primary and premotor cortex, area 5 seems to be less directly involved in control of musculoskeletal dynamics: it appears to be insensitive to external force load, and to encode movement kinematics instead of dynamics (Kalaska et al., 1990). Also, many area 5 neurons show strong firing patterns that continuously covary with hand trajectory (Archambault et al., 2011; Hauschild et al., 2012), a manually/brain controlled cursor (Mulliken et al., 2008), or even the seen position of a realistic fake arm (Graziano et al., 2000).

Although both the PRR and area $5 d$ have been found to be intimately involved in planning of reach, several recent studies of reference frame, decision making, and sequential movement suggest that they might play distinct roles in planning and control of reaching arm movement at different (abstract vs concrete) levels of complexity (Fig. $1 B$ ), indicating a hierarchical circuitry that is involved in translation from cognitive intention into detailed motor programs to implement a key step of the complex sensorimotor transformations from receptors to muscle activation patterns.

\section{Reference Frame}

The first findings in favor of a hierarchical PRR-area $5 d$ circuitry emerged from experiments characterizing sensorimotor coordinates with a variety of combinations of target, eye, and hand positions (Andersen at al., 1997). Unlike an oculomotor plan in eye-centered coordinates that is always registered to its sensory target in a retinotopic map, goal-directed reach initially planned in visual space (Flanagan and Rao, 1995; Wolpert et al., 1995) requires a transformation from extrapersonal to joint/muscle coordinates. Recent studies demonstrate that different coordinate systems are employed in the PRR and area 5d (Batista et al., 1999; Bremner and Andersen, 2012), suggesting that these areas are involved in reach planning in extrinsic and intrinsic spaces, respectively.

Neurophysiological recordings during a delayed-reach task revealed a gradient distribution in the medial wall of the IPS, with deep (superficial) neurons tending to be more modulated in the cue (movement) epoch (Johnson et al., 1996), suggesting that they are involved in different stages of the sensorimotor transformation (BattagliaMayer et al., 2003). Reaching goals have been found to be represented in retinal coordinates (Batista et al., 1999; Pesaran et al. 2006) in the PRR, indicating a cognitive plan at a more conceptual level than at the subsequent stages of motor planning. That is, the PRR only conveys abstract information (i.e., the spatial goal) about upcoming movements, without specifying physical movement parameters (i.e., joint angles). Nonetheless, accurate motor control must take into account intrinsic variables, such as posture, hand position, the dynamics and structure of muscles, etc. Therefore, abstract motor intentions ultimately must be converted into detailed physical motor plans, with movement parameters specified in muscle/joint coordinates to activate musculoskeletal system (Kalaska et al., 1997). The first step in converting target location in gaze-centered coordinates into limb motor commands for reaching is to incorporate proprioceptive and efference copy information about starting hand position and intrinsic arm posture. It seems likely that area $5 d$ plays a key role in this stage by providing target information with respect to initial hand position to specify action parameters in musculoskeletal coordinates (Buneo et al., 2002). From the PRR to area $5 d$, neuronal representations of the reaching goal progressively shift from eye-centered to hand-centered along the ventral-dorsal axis of the medial bank of the IPS (Buneo and Andersen, 2006), so that pre-movement activity in area $5 \mathrm{~d}$ predominantly encodes the reach vector (Bremner and Andersen, 2012). However, this hand-centered coding is not static, but gradually emerges during the reach planning period (Bremner and Andersen, 2014), supporting the view that area $5 d$ integrates the intrinsic biomechanics of the musculoskeletal system by dynamically incorporating information about intrinsic arm posture.

\section{Decision Making}

Another approach to elucidating parietal sensorimotor circuitry is to identify distinct functional areas for decision making and motor planning. Decision making initially was assumed to be a neural process separate from action planning (Miller et al., 1960; Keele, 1968). Nevertheless, attempts to distinguish decision making from motor planning with target selection tasks have proven frustrating, because virtually all motor-related areas seem to convey potential movements to candidate targets, and multiple potential plans exist concurrently before the final action is chosen (Riehle and Requin, 1989; Platt and Glimcher, 1997; Basso and Wurtz, 1998; Cisek and Kalaska, 2005). Consequentially, it is commonly believed that target selection and movement preparation involve overlapping brain circuits, and are performed in an integrated manner, as opposed to a serial model in which decision making occurs before action planning (Shadlen and Newsome, 2001; Wang, 2008; Cisek and Kalaska, 2010). From the evolutionary point of view, forming multiple potential action plans prior to choosing among them might not only benefit reward prediction, but might also reduce reaction time (Andersen and Cui, 2009; Cisek and Kalaska, 2010). Nevertheless, the idea of integrated circuitry for decision making and motor planning has only been tested for spatial target selection (Cisek, 2007), which involves spatial attention, and in turn engages numerous cortical areas (Desimone and Duncan, 1995). It is unclear if plan selection and action preparation are embedded in segregated 
areas for other kinds of decision making, such as nonspatial effector choice.

To examine anatomical overlap for decision making and motor planning in nonspatial action selection, an effectorchoice task was designed in which monkeys autonomously chose between a saccade and a hand reach to the same visual stimulus (Cui and Andersen, 2007). Monkeys were required to play a mixed-strategy game against a computer (Barraclough et al., 2004) to compensate for a potential bias due to movement costs. The effectorchoice trials were pseudo-randomly interleaved with effector-instructed trials in which the monkeys were explicitly cued to make either a saccade or a reach to the target in the middle of a trial to discourage premature decisions. The effector-choice task allows potential motor plans to be formed without immediate specification of concrete motor parameters controlling a particular endeffector, providing an ideal paradigm to determine whether action selection and motor preparation are encoded in overlapping or in distinct areas in nonspatial decision making. If a brain region is involved in effector decision formation, then it should encode potential motor plans prior to effector selection. Conversely, if an area only carries selected motor plans, then it should only reflect the decision outcome after the effector is unambiguously specified. Interestingly, recent studies demonstrate remarkable qualitative differences between LIP/ PRR and area 5d (Cui and Andersen, 2007, 2011). Whereas the LIP and PPR encode potential motor plans, area $5 d$ encodes only selected reach plans after the arm is chosen as the effector, suggesting that it is downstream to the PRR in a serial visuomotor cortical circuit (Cui and Andersen, 2011). While the PRR and area $5 d$ presumably work in concert with premotor and primary motor areas, respectively (Wise et al., 1997), the functional relationship between the parietal and frontal areas in effector choice remains unclear.

\section{Sequential Planning}

In contrast to the prefrontal cortex (Tanji, 2001), the PPC has historically received little attention in studies of sequential planning. Nonetheless, neurological studies have suggested that the PPC is crucial for serial behaviour (Buxbaum, 1998; Zadikoff and Lang, 2005). Patients with damage to the left parietal lobe appear normal in performing elementary movements, but are impaired in generating complex action sequences, indicating a profound role of the PPC in integrating multiple spatial goals into a motor sequence.

To reveal the functional role of PPC in sequential arm movements, single-neuron activity from the PRR (Baldauf et al., 2008) and area 5d (Li and Cui, 2013) has been recorded from monkeys performing a double-reach task. When the monkeys prepared to reach two simultaneously presented targets with sequential arm movements, most PRR neurons carried information about both the immediate and the subsequent goals (Baldauf et al., 2008). Situated at the early stage of the visuomotor transformation, the PRR presumably is involved in the first step to generate a coherent sequence, integrating information about all component movements into a high-level movement plan at an abstract level. Nevertheless, a conceptual sequential plan encompassing multiple goals in parallel ultimately must be decomposed into serial motor commands to drive the musculoskeletal system. In contrast to the PRR, area $5 \mathrm{~d}$ has been found to only encode the immediate upcoming reach, and not the subsequent movement (Li and Cui, 2013). Area $5 d$ activity is tightly coupled only to the next upcoming movement, suggesting it might play a key role in integrating the visual goals from the PRR with physical limb information to form a state estimation (Mulliken et al., 2008; Shi et al., 2013). Moreover, the component reach encoded in area $5 d$, as opposed to the sequential information being conveyed in the PRR and other cortical sensorimotor areas, suggests that unfolding of the movement sequence begins in the parietal-frontal cortex, including the PPC, prefrontal cortex, premotor cortex, primary motor cortex, and supplemental motor cortex, instead of being exclusively conducted by downstream subcortical and spinal circuits. Again, decomposition of the motor sequence appears to engage a larger sensorimotor network via mutual communication between parietal and frontal cortices (Pesaran et al., 2008).

\section{Discussion}

A series of recent experiments have been conducted on monkeys performing a variety of sensorimotor tasks to elucidate distinct roles of the PRR and area $5 d$ at different stages of the sensorimotor transformation. First, the reference frame task allowed us to isolate general motor intentions in extrinsic space and physical movement preparation in intrinsic space. Second, the effector-choice task allowed potential action plans to be formed without immediate specification of the concrete motor parameters controlling the end-effector. Third, the sequential reach task enabled us to isolate the cognitive action sequence from the detailed motor program of element movements. Three lines of evidence obtained with these tasks suggest that the PRR and area $5 \mathrm{~d}$ form a hierarchical sensorimotor circuitry that translates abstract intentions into detailed motor plans.

Despite the markedly different functional roles between PRR and area 5d, we should keep in mind that they are not sequentially involved in converting extrinsic stimuli into intrinsic motor plans in a hardwired fashion. First, although a serial neural process was observed in the sensorimotor tasks mentioned above, effector specificity and information flow might be different in behavioral contexts other than visually guided reach (e.g., Swaminathan et al., 2013; Woloszyn and Shadlen, 2013). Secondly, behavioral and computational studies have suggested that the sensorimotor transformation emerges through an intimate interplay between sensory inflow and motor outflow through paired forward and inverse internal models (Wolpert and Kawato, 1998; Shadmehr and Wise, 2005): the forward model translates motor commands into anticipated sensory outcomes, whereas the inverse model converts desired sensory consequences into motor commands (Franklin and Wolpert, 2011; Shadmehr and 
Mussa-Ivaldi, 2012). Although the prevalent view posits that sensorimotor control largely relies on forward prediction of sensory consequences (Wolpert et al., 2011), direct neurophysiological evidence that persuasively links neural firing to predicted sensory consequences is still lacking, because the internal prediction of sensory consequences is inherently different from actual sensorimotor variables, and seems not to be behaviorally measurable. Since most previous studies have used reactive movements to stationary goals predefined by sensory cues, it is difficult to determine whether the neural activity observed reflects sensory stimuli or predicts impending movements. Although corollary discharges have been found in diverse species (Crapse and Sommer, 2008) for gating sensory inputs (e.g., Lee and Malpeli, 1998) and updating perception (e.g., Duhamel et al., 1992; Sommer and Wurtz, 2002; Synofzik et al., 2008), as well as for distinguishing sensory signals between active and passive motion (e.g., Roy and Cullen, 2004), it remains unclear how they are integrated with sensory inflow in recipient structures to form internal models for directing movement. Further elucidation of the PPC sensorimotor circuitry calls for novel behavioral tasks that are highly dependent on predictive spatiotemporal transformations.

\section{References}

Andersen RA, Buneo CA (2002) Intentional maps in posterior parietal cortex. Annu Rev Neurosci 25:189-220. CrossRef Medline

Andersen RA, Cui H (2009) Intention, action planning, and decision making in parietal-frontal circuits. Neuron 63:568-583. CrossRef Medline

Andersen RA, Snyder LH, Bradley DC, Xing J (1997) Multimodal representation of space in the posterior parietal cortex and its use in planning movements. Ann Rev Neurosci 20:303-330. CrossRef Medline

Archambault PS, Ferrari-Toniolo S, Battaglia-Mayer A (2011) Online control of hand trajectory and evolution of motor intention in the parietofrontal system. J Neurosci 31:742-752. CrossRef Medline

Baldauf D, Cui H Andersen RA (2008) The posterior parietal cortex encodes in parallel both goals for double-reach sequences. J Neurosci 28:10081-10089. CrossRef Medline

Barraclough DJ, Conroy ML, Lee D (2004) Prefrontal cortex and decision making in a mixed-strategy game. Nat Neurosci 7:404410. CrossRef Medline

Basso MA, Wurtz RH (1998) Modulation of neuronal activity in superior colliculus by changes in target probability. J Neurosci 18: 7519-7534. Medline

Batista AP, Buneo CA, Snyder LH Andersen RA (1999) Reach plans in eye-centered coordinates. Science 285:257-260. Medline

Battaglia-Mayer A, Caminiti R, Lacquaniti F, Zago M (2003) Multiple levels of representation of reaching in the parieto-frontal network. Cereb Cortex 13:1009-1022. Medline

Bremner LR, Andersen RA (2012) Coding of the reach vector in parietal area 5d. Neuron 75:342-351. CrossRef Medline

Bremner LR, Andersen RA (2014) Temporal analysis of reference frames in parietal cortex area $5 d$ during reach planning. J Neurosci 34:5273-5284. CrossRef Medline

Buneo CA, Andersen RA (2006) The posterior parietal cortex: sensorimotor interface for the planning and online control of visually guided movements. Neuropsychologia 44:2594-2606. CrossRef Medline

Buneo CA, Jarvis MR, Batista AP Andersen RA (2002) Direct visuomotor transformations for reaching. Nature 416:632-636. CrossRef Medline
Buxbaum LJ (1998) Ideational apraxia and naturalistic action. Cogn Neuropsychol 15:617-643. CrossRef Medline

Cisek P (2007) Cortical mechanisms of action selection: the affordance competition hypothesis. Trans R Soc Lond B Biol Sci 362:1585-1599. CrossRef Medline

Cisek P, Kalaska JF (2005) Neural correlates of reaching decisions in dorsal premotor cortex: specification of multiple direction choices and final selection of action. Neuron 45:801-814. CrossRef Medline

Cisek P, Kalaska JF (2010) Neural mechanisms for interacting with a world full of action choices. Annu Rev Neurosci 33:269-298. CrossRef Medline

Colby CL, Goldberg ME (1999) Space and attention in parietal cortex. Annu Rev Neurosci 22:319-349. CrossRef Medline

Crapse TB, Sommer MA (2008) Corollary discharge across the animal kingdom. Nat Rev Neurosci 9:587-600. CrossRef Medline

Critchley M (1953) The parietal lobe. London: Arnold.

Cui H, Andersen RA (2007) Posterior parietal cortex encodes autonomously selected motor plans. Neuron 56:552-559. CrossRef Medline

Cui H, Andersen RA (2011) Different representations of potential and selected motor plans by distinct parietal areas. J Neurosci 31: 18130-18136. CrossRef Medline

Desimone R, Duncan J (1995) Neural mechanisms of selective visual attention. Annu Rev Neurosci 18:193-222. CrossRef Medline

Duhamel JR, Colby CL, Goldberg ME (1992) The updating of the representation of visual space in parietal cortex by intended eye movements. Science 255:90-92. Medline

Flanagan JR, Rao AK (1995) Trajectory adaptation to a nonlinear visuomotor transformation: evidence of motion planning in visually perceived space. J Neurophysiol 74: 2174-2178.

Franklin DW, Wolpert DM (2011) Computational mechanisms of sensorimotor control. Neuron 72:425-442. CrossRef Medline

Gail A, Andersen RA (2006) Neural dynamics in monkey parietal reach region reflect context-specific sensorimotor transformations. J Neurosci 26:9376-9384. CrossRef Medline

Graziano MS, Cooke DF, Taylor CS (2000) Coding the location of the arm by sight. Science 290:1782-1786. Medline

Hauschild M, Mulliken GH, Fineman I, Loeb GE Andersen RA, (2012) Cognitive signals for brain-machine interfaces in posterior parietal cortex include continuous 3D trajectory commands. Proc Natl Acad Sci U S A 109:17075-17080. CrossRef Medline

He SQ, Dum RP, Strick PL (1993) Topographic organization of corticospinal projections from the frontal lobe: motor areas on the lateral surface of the hemisphere. J Neurosci 13:952-980. Medline

Heed T, Beurze SM, Toni I, Roder B, Medendorp WP (2011) Functional rather than effector-specific organization of human posterior parietal cortex. J Neurosci 31:3066-3076. CrossRef Medline

Hwang EJ, Hauschild M, Wilke M Andersen RA (2012) Inactivation of the parietal reach region causes optic ataxia, impairing reaches but not saccades. Neuron 76:1021-1029. CrossRef Medline

Johnson PB, Ferraina S, Bianchi L, Caminiti R (1996) Cortical networks for visual reaching: physiological and anatomical organization of frontal and parietal lobe arm regions. Cereb Cortex 6:102119. Medline

Jones EG, Coulter JD, Hendry SH (1978) Intracortical connectivity of architectonic fields in the somatic sensory, motor and parietal cortex of monkeys. J Comp Neurol 181:291-347. CrossRef Medline

Kalaska JF, Crammond DJ (1995) Deciding not to GO: neuronal correlates of response selection in a GO/NOGO task in primate premotor and parietal cortex. Cereb Cortex 5:410-428. Medline

Kalaska JF, Caminiti R, Georgopoulos AP (1983) Cortical mechanisms related to the direction of two-dimensional arm movements: relations in parietal area 5 and comparison with motor cortex. Exp Brain Res 51:247-260. Medline

Kalaska JF, Cohen DA, Prud'homme M, Hyde ML (1990) Parietal area 5 neuronal activity encodes movement kinematics, not movement dynamics. Exp Brain Res 80:351-364. Medline 
Kalaska JF, Scott SH, Cisek P, Sergio LE (1997) Cortical control of reaching movements. Curr Opin Neurobiol 7:849-859. Medline

Keele SW (1968) Movement control in skilled motor performance. Psychol Bull 70:387-403.CrossRef

Lacquaniti F, Guigon E, Bianchi L, Ferraina S, Caminiti R (1995) Representing spatial information for limb movement: role of area 5 in the monkey. Cereb Cortex 5:391-409. Medline

Lee D, Malpeli JG (1998) Effects of saccades on the activity of neurons in the cat lateral geniculate nucleus. J Neurophysiol 79: 922-936. Medline

Leone FT, Heed T, Toni I, Medendorp WP (2014) Understanding effector selectivity in human posterior parietal cortex by combining information patterns and activation measures. J Neurosci 34: 7102-7112. CrossRef Medline

Li Y, Cui H, (2013) Dorsal parietal area 5 encodes immediate reach in sequential arm movements. J Neurosci 33:14455-14465. CrossRef Medline

Miller GA, Galanter E, Pribram KH (1960) Plans and the structure of behavior. New York: Holt, Rinehart and Winston.

Mountcastle VB (1998) Perceptual neuroscience: the cerebral cortex. Cambridge, MA: Harvard UP.

Mountcastle VB, Lynch JC, Georgopoulos AP, Sakata H, Acuna C (1975) Posterior parietal association cortex of the monkey: command functions for operations within extrapersonal space. J Neurophysiol 38:871-908. Medline

Mulliken GH, Musallam S, Andersen RA (2008) Forward estimation of movement state in posterior parietal cortex. Proc Natl Acad Sci U S A 105:8170-8177. CrossRef Medline

Pearson RC, Powell TP (1985) The projection of the primary somatic sensory cortex upon area 5 in the monkey. Brain Res 356:89-107. Medline

Pesaran B, Nelson MJ, Andersen RA (2006) Dorsal premotor neurons encode the relative position of the hand, eye, and goal during reach planning. Neuron 51:125-134. CrossRef Medline

Pesaran B, Nelson MJ, Andersen RA (2008) Free choice activates a decision circuit between frontal and parietal cortex. Nature. 453: 406-409. CrossRef Medline

Platt ML, Glimcher PW (1997) Responses of intraparietal neurons to saccadic targets and visual distracters. J Neurophysiol 78:15741589. Medline

Quian Quiroga R, Snyder LH, Batista AP, Cui H Andersen RA (2006) Movement intention is better predicted than attention in the posterior parietal cortex. J Neurosci 26:3615-3620. CrossRef Medline

Riehle A, Requin J (1989) Monkey primary motor and premotor cortex: single-cell activity related to prior information about direction and extent of an intended movement. J Neurophysiol 61:534549. Medline

Rizzolatti G, Kalaska J (2013) Voluntary movement: the parietal and premotor cortex. In: Principles of neural science (Kandel ER, Schwartz JH, Jessell TM, Siegelbaum SA, Hudspeth AJ, eds), pp 863-893. New York: McGaw-Hill.

Rizzolatti GL, Fogassi L, Gallese V (1997) Parietal cortex: from sight to action. Curr Opin Neurobiol 7:562-567. Medline

Roy JE, Cullen KE (2004) Dissociating self-generated from passively applied head motion: neural mechanisms in the vestibular nuclei. $J$ Neurosci 24:2102-2111. CrossRef Medline

Sakata H, Takaoka Y, Kawarasaki A, Shibutani H (1973) Somatosensory properties of neurons in the superior parietal cortex (area 5) of the rhesus monkey. Brain Res 64:85-102. Medline

Scherberger H, Andersen RA (2007) Target selection signals for arm reaching in the posterior parietal cortex. J Neurosci 27:2001-2012. CrossRef Medline

Scherberger H, Quian Quiroga R, Andersen RA (2013). Coding of movement intentions. In: Principles of neural coding (Quian Quiroga R, Panzeri S, eds), pp 303-321. Boca Raton, FL: CRC.
Shadlen MN, Newsome WT (2001) Neural basis of a perceptual decision in the parietal cortex (area LIP) of the rhesus monkey. $J$ Neurophysiol 86:1916-1936. Medline

Shadmehr R, Mussa-Ivaldi S (2012) Biological learning and control: how the brain builds representations, predicts events, and makes decisions. Cambridge: MIT.

Shadmehr R, Wise SP (2005) The computational neurobiology of reaching and pointing: a foundation for motor learning. Cambridge: MIT.

Shi Y, Apker G, Buneo CA (2013) Multimodal representation of limb endpoint position in the posterior parietal cortex. J Neurophysiol 109:2097-2107. CrossRef Medline

Snyder LH, Batista AP Andersen RA (1997) Coding of intention in the posterior parietal cortex. Nature 386:167-170. CrossRef Medline

Sommer MA, Wurtz RH (2002) A pathway in primate brain for internal monitoring of movements. Science 296:1480-1482. CrossRef Medline

Strick PL, Kim CC (1978) Input to primate motor cortex from posterior parietal cortex (area 5). I. Demonstration by retrograde transport. Brain Res 157:325-330. Medline

Swaminathan SK, Masse NY, Freedman DJ (2013) A comparison of lateral and medial intraparietal areas during a visual categorization task. J Neurosci 33:13157-13170. CrossRef Medline

Synofzik M, Lindner A, Their P (2008) The cerebellum updates predictions about the visual consequences of one's behavior. Curr Biol 18:814-818. CrossRef Medline

Tanji J (2001) Sequential organization of multiple movements: involvement of cortical motor areas. Annu Rev Neurosci 24:631651. CrossRef Medline

Torres EB, Andersen RA (2006) Space-time separation during obstacle-avoidance learning in monkeys. J Neurophysiol 96:26132632. CrossRef Medline

Torres EB, Zipser D (2002) Reaching to grasp with a multi-jointed arm. I. Computational model. J Neurophysiol 88:2355-2367. CrossRef Medline

Torres EB, Quian Quiroga R, Cui H, Buneo CA (2013) Neural correlates of learning and trajectory planning in the posterior parietal cortex. Front Integr Neurosci 7:39.CrossRef Medline

Ungerleider LG, Mishkin M (1982) Two cortical visual systems. In: Analysis of visual behavior (Ingle DJ, Goodale MA, Mansfield RJ, eds.), pp 549. Cambridge: MIT.

Verhagen L, Dijkerman HC, Medendorp WP, Toni I, (2013) Hierarchical organization of parietofrontal circuits during goal-directed action. J Neurosci 33:6492-6503. CrossRef Medline

Wang XJ (2008) Decision making in recurrent neuronal circuits. Neuron 60:215-234. CrossRef Medline

Wise SP, Boussaoud D, Johnson PB, Caminiti R (1997) Premotor and parietal cortex: corticocortical connectivity and combinatorial computations. Annu Rev Neurosci 20:25-42. CrossRef Medline

Woloszyn L, Shadlen MN (2013) Responses of neurons in cortical areas LIP and MIP during a reaction time perceptual decisionmaking task communicated with an eye or a hand movement. Soc Neurosci Abstr 13:668.13.

Wolpert DM, Kawato M (1998) Multiple paired forward and inverse models for motor control. Neural Netw 11:1317-1329. Medline

Wolpert DM, Ghahramani Z, Michael I, Jordan MI (1995) Are arm trajectories planned in kinematic or dynamic coordinates? an adaptation study. Exp Brain Res 103:460-470. Medline

Wolpert DM, Diedrichsen J, Flanagan JR (2011) Principles of sensorimotor learning. Nat Rev Neurosci 12:739-751. CrossRef Medline

Zadikoff C, Lang AE (2005) Apraxia in movement disorders. Brain 128:1480-1497. CrossRef Medline 